\title{
Pure and compensated technical efficiency of Swedish dairy farms
}

\author{
Manevska-Tasevska Gordana ${ }^{1,2,3}$, Rabinowicz Ewa², \& Surry Rene Yves ${ }^{3}$ \\ ${ }^{1}$ AgriFood Economics Centre, Department of Economics, Swedish University of Agricultural Sciences, Box 7013, 75007 Uppsala, \\ Sweden \\ ${ }^{2}$ AgriFood Economics Centre, Department of Economics, Swedish University of Agricultural Sciences, Box 730, 22007 Lund, \\ Sweden \\ ${ }^{3}$ Department of Economics, Swedish University of Agricultural Sciences, \\ Box 7013, 75007 Uppsala, Sweden \\ email: gordana.tasevska@slu.se
}

\begin{abstract}
The compensatory effect of environmental subsidies for agri-environmental output constraints was evaluated through a comparative analysis observing the 'pure' technical efficiency, as a benchmark for prevailing production conditions, and the 'compensated' technical efficiency, as a proxy indicator of the compensation. An unbalanced data panel covering 3578 observations of 668 Swedish dairy farms in the period 2002-2012 was used. The analysis showed that in the study period, environmental farm support decreased the differences in farm revenue generated by agri-environmental output constraints in Sweden. However, the environmental support distribution did not succeed in meeting regional needs, so difficulties emerged in farmers' ability to generate output in southern and central forest and valley areas of Sweden. Furthermore, the environmental agricultural support had only a partial subsidisation effect on 'output-reducing' farm management practices, with full compensation being achieved for organic and capital-extensive farming, whereas low livestock density farming was not sufficiently compensated for. This analysis reveals incentives with policy implications for farm technical performance and provides direct input to future policy recommendations for environmental support allocation.
\end{abstract}

Key words: compensated technical efficiency, dairy farms, environmental support, pure technical efficiency, Sweden

\section{Introduction}

In the European Union (EU), compensation is provided to farmers for losses in agricultural output values and higher operating costs originating from decreased potential for agriculture due to operating in regions with natural or other specific constraints, i.e. environmentally sensitive regions or application of output-reducing farm management practices (such as organic farming, fulfilling other cross-compliance requirements on maintaining pasture areas, conservation agriculture, animal welfare, etc.) (EC 2016). Thus, within the platform of the EU's common agricultural policy (CAP), financial support is provided to EU farmers to compensate them for unfavourable conditions whereby they cannot compete equally with farms operating in other regions or with conventional practices. The agri-environmental payments provided within the framework of Pillar II measures are adjusted based on the principle that output differences (i.e. eventual lower output value) caused by environmental management practices and by operating in environmentally sensitive regions are rectified.

The ability of farmers to generate output can be interpreted as a level of agri-environmental pressure on farm efficiency (Latruffe and Nauges 2013). The findings to date consistently show that farms exposed to environmental constraints are less efficient (McCloud and Kumbhakar 2008, Sipiläinen et al. 2009, Kumbhakar and Lien 2010, Manevska-Tasevska et al. 2014). An unavoidable question in this regard is how farms operating in environmentally sensitive regions and/or applying output-reducing farm management practices fare under such conditions. Moreover, although largely regarded as being expensive for producers, interest in sustainable agriculture, food safety, health and animal welfare is increasing, and organic production is continuing to expand in many regions (EC 2013). Farm diversification in terms of utilising underexploited resources and environmentally friendly agriculture continues to be highly prioritised within environmental policy schemes. In the literature during the past decade, diversification of farm activities has regularly been related to positive economic results in terms of farm efficiency (Hadley 2006, Hansson 2007, Barnes and Revoredo-Giha 2011) and farm viability (Barnes et al. 2015). Barnes (2006) showed that multi-functional farming, in terms of farming driven by economic, social and environmental goals, has a positive effect on technical efficiency, although it is generally expected that dairy farming that relies on labour-intensive feeding and milking or extensive grazing cannot be economically viable without subsidisation. The common expectation that intensive farming, or 'industrial farming', is more efficient originates from the precision agriculture approach (Tilman et al. 2002), characterised by typically large-scale intensive systems with innovative mechanisation, high livestock density and high specialisation. 
In a study in Spain, Alvarez et al. (2008) showed that higher milk production per cow and hectare, higher feed use and higher density lead to more efficient dairy farming.

Although farms operating in environmentally sensitive regions and/or applying output-reducing farm management practices are known to be highly dependent on subsidies (Acs et al. 2009, Breustedt et al. 2011) and derive on average greater benefits from policy support (McCloud and Kumbhakar 2008), knowledge of the effects of subsidies in compensating for agricultural output losses owing to environmental and/or production restrictions is still lacking. Such knowledge could help identify the importance of farm support for the survival of farms, suitable practices for rural development programme evaluations and future policy recommendations for support allocation.

The main objective of this study was thus to examine whether the environmental agricultural support provided within the Pillar II framework has succeeded in eliminating the influence of regional differences in potential for agriculture and output-reducing farm management practices on farm efficiency. A satisfactory, well-distributed compensation system is expected to negate the constraints on farming in terms of revenue generation, increasing the possibility for the least efficient to achieve the revenue obtained by the most efficient farms. A comparative analysis was conducted on the output-oriented 'pure technical efficiency' (PTE) (or TE estimated without Pillar II subsidies included in total farm revenue), as a benchmark for the prevailing revenue-generating capacity of farms, and the 'compensated technical efficiency' (CTE) (or TE estimated with the Pillar II subsidy included in total farm revenue), showing the subsidy compensation effect.

Data from the Swedish Farm Accounting Survey (FAS) for the period 2002-2012 on farms specialising in dairy production were used. Dairy farming in Sweden is spread across regions with both intensive and restricted potential for agriculture using either conventional or organic farming practices. In particular, the proportion of organically managed area in Sweden (16\%) is among the highest in the EU (Statistics Sweden 2014), after Austria (19\%), and is continuing to grow (EC 2013). Furthermore, Sweden is among the countries with the highest distribution of rural development support in the EU and has among the highest marginal product of subsidies for dairy farms (McCloud and Kumbhakar 2008). During the period 2000-2006, for example, rural development support was distributed to $86 \%$ of Swedish farms included in the national Farm Accounting Data Network (FADN) (EC 2009). In addition to environmental support, Swedish dairy producers are recipients of a special compensatory payment, 'Nordic aid', provided to ensure that agricultural activity is maintained in the Nordic region (Brady et al. 2007). Given the characteristics of the dataset, differences in output efficiency as a result of pressure originating from agri-environmental production constraints and regional agricultural potential were expected.

As mentioned previously, the EU CAP is designed to support farming that promotes balanced regional development and compensates for production conditions that restrain agricultural production across all Europe's rural areas. This is the first attempt at comparative efficiency analysis observing PTE and CTE as a proxy for the Pillar II compensation effect on farm efficiency. In the efficiency literature, policy conclusions are drawn based on analyses where the subsidy is, or is not, considered part of farm output. The present study used the same dataset and compared the gaps between the TEs obtained with the two approaches. The results have policy implications for farm technical performance and thus represent direct input to future policy recommendations for support allocation. Appropriately distributed compensation can potentially contribute to keeping farming and rural areas alive, protecting the environment and biodiversity and improving animal welfare and the quality of farm product standards.

\section{Method}

\section{Analytical framework}

The analytical framework builds on the circumstance that a large share of total revenue for farms located in regions with lower agricultural potential and/or applying output-reducing farm management practices comes from subsidies. The losses of revenue originating from the decreased agricultural potential in such conditions are basically expected to be compensated for by subsidisation. According to Sipiläinen and Huhtala (2013), the general public largely views agri-environmental support as subsidy programmes to compensate for the costs of conservation measures. In the present study, the success of Pillar II agricultural support in compensating farmers was evaluated through a comparative analysis observing PTE and CTE, where farm efficiency is observed in terms of farm ability to generate output/revenue, i.e. 'output-oriented efficiency' (Coelli et al. 2005). Here PTE was assumed to act as a benchmark for the prevailing production conditions, and thus farm production capacity, while CTE was assumed to show whether differences in output efficiency between farms operating in environmentally sensitive circumstances and under regular conditions for farming decrease when Pillar II support payments are distributed. 
According to Rasmussen (2011), subsidies must be considered and included in production technology systems, either as a cost reduction or as an output. However, in order to be counted as a cost reduction, details of the contribution of the support to the costs of specific inputs are necessary. In the current scheme, the CAP payments (including both Pillar I and Pillar II) are not adjusted for the operating costs on farms or for farm input use, and therefore inclusion of such support as a cost reduction or as an endogenous input is impossible. Moreover, a large proportion of the EU rural development support (Pillar II payments) is provided for generating common benefits, such as increasing social capital, sustainable management of the landscape, and environmental and economic benefits (Prager 2015), so considering payments as inputs that are not fully used for output creation can mean overestimation of input use. In other studies, subsidies are considered a traditional input (Zhengfei and Lansink 2006, McCloud and Kumbhakar 2008) or an endogenous input variable included in the production technology system and an exogenous variable explaining the inefficiency model (e.g. Kumbhakar and Lien 2010).

In the present study, the total Pillar II subsidy amount received by the farms studied was integrated into farm output, as done by e.g. Barnes (2008), Hadley (2006) and Rasmussen (2011). This allowed the CTE to be estimated and the output-oriented efficiency scores before and after subsidy distribution, namely PTE and CTE, to be compared. While estimating the output efficiency of English and Welsh farms, Hadley (2006) considered subsidies and grants to be part of the total amount of money received by the farmers, i.e. farm output/revenue. Using that approach, environmentally sensitive or less favoured areas (LFA), which in efficiency studies are regularly found to be less efficient, were not found to be an important factor for the efficiency of English and Welsh farms, most likely due the inclusion of subsidies in the revenue and their compensatory effect. However, on using Hadley's approach of including subsidies and grants in farm revenue, Barnes (2008) found LFA regions to be significantly less efficient for farms in Scotland, where around $80 \%$ of land is designated LFA.

The parametric Stochastic Frontier Approach (SFA) (Aigner et al. 1977, Meeusen and Broeck 1977), conducted in STATA, was applied here. SFA estimates farm TE by measuring the distance between the observed and "best" feasible input-output combination of farms given the highest possible amount of output/revenue that can be obtained (while keeping the amount of inputs fixed), i.e. it is an output-oriented approach (Coelli et al. 2005). After the likelihood test, the Translog form was selected as more appropriate than the Cobb Douglas form, with likelihood ratio (LR) statistics for the PTE and CTE model as follows: $L R_{P T E}=98.44$, Prob $>$ chi2 ${ }_{P T E}=0.0000 ; L R_{C T E}=122.14$, Prob $>$ chi2 ${ }_{\text {CTE }}=0.0000$.

Where balanced panel data are available, models for panel data are preferable and can be expected to control for unobserved differences between observations, capturing the 'firm effect' and adding a time dimension to the analysis (Fried et al. 2008, Parmeter and Kumbhakar 2014). The present analysis was based on a rotating unbalanced panel dataset where, even though the average appearance of the farms in the dataset was five years, large numbers of farms appeared for a period shorter than three years. Although panel models using both the fixed and random effects were initially favoured, convergence was not achieved. We suspect that one possible problem might be the short duration of inclusion of some farms, making the estimates subject to small sample bias, and another might be the highly nonlinear nature of the Translog function. Therefore such an application was rejected, and the pooled frontier model using linear regression was deemed more appropriate.

The general stochastic frontier model for pooled data (equation [1]), the Trans-log stochastic frontier production function (equation [2] \& [3]) specifications and the inefficiency variance function (equation [4]) used in this study were as follows:

$$
y_{i}=f\left(x_{i}, t, \beta\right) e^{\left(v_{i}-u_{i}\right)}
$$

where in the production function (equation [1]), $y_{i}$ is total farm revenue (expressed in natural logarithm) of the $i^{\text {th }}$ farm; $f()$ is the production function (Trans-log was selected as most suitable) containing: $x_{i}$ as a vector of inputs used in the production process (expressed in natural logarithm), $t$ is a scale for the time period $(t=1,2$, ... 11), $\beta$ is parameters to be estimated; and $e^{(.)}$is a random error term containing a random noise term $v_{i}$ for the production shocks and $u_{i}$ as an inefficiency term. The functional form applied for PTE and CTE was:

PTE:

$$
\ln y_{i}=\alpha_{0}+\sum_{k=1}^{5} \beta_{k} \ln x_{i k}+\frac{1}{2} \sum_{k=1}^{5} \sum_{i=1}^{5} \beta_{k l} \ln x_{i k} \ln x_{i l}+\gamma t+\gamma t^{2}+v_{i}-u_{i}
$$

CTE:

$$
\ln \left(y_{i}+s_{i}\right)=\alpha_{0}+\sum_{k=1}^{5} \beta_{k} \ln x_{i k}+\frac{1}{2} \sum_{k=1}^{5} \sum_{l=1}^{5} \beta_{k l} \ln x_{i k} \ln x_{i l}+\gamma t+\gamma t^{2}+v_{i}-u_{i}
$$


In the Trans-log stochastic frontier production function (equation [2] for PTE and equation [3] for CTE), the farm revenue $y_{i}$ (expressed in natural logarithm) obtained for the $i^{i \text { th }}$ farm is a function of the inputs $x^{i}$ (expressed in natural logarithm) used in the production process; In denotes the natural logarithm; $s_{i}$ the total amount of Pillar II agricultural support joining the total farm revenue $y_{i}$ for the CTE specification; $\alpha_{0}$ is a constant; $\beta$ and $\gamma$ are parameters to be estimated; $\mathrm{t}$ is a linear trend, capturing the adoption of technical change $(2002=1 \ldots, 2012=11) ; \mathrm{k}$ and I are two inputs; $v_{i}$ is random noise, independently and identically distributed $N\left(0, \sigma_{v}^{2}\right)$. an inefficiency term.

In a stochastic frontier model with output-oriented specification, the inefficiency term $u_{i}$ represents the log difference between the maximum attainable output and the actual output (Kumbhakar et al. 2015). For equation (2), i.e. for PTE, $u_{i}=\ln y_{i}^{*}-\ln y_{i}$. For equation (3), i.e. for CTE, ui $=\ln \left(y_{i}+s_{i}\right)^{*}-\ln \left(y_{i}+s_{i}\right)$. The inefficiency term is then

$$
\exp \left(-u_{i}\right)=\frac{y_{i}}{y_{i}^{*}} \text { and } \exp \left(-u_{i}\right)=\frac{y_{i}+s_{i}}{\left(y_{i}+s_{i}\right)^{*}} \text {, respectively. Since the observed output is bounded below the frontier }
$$

output level (the maximum attainable output), $u_{i} \geq 0$ and the value of the estimated TE coefficient ranges between 0 and 1 , denoting farm efficiency of between $0 \%$ and $100 \%$.

The inefficiency variance function (Battese and Coelli 1995) in equation (4) is explained by $z_{i}$, the vector of variables associated with the inefficiency sources; $\delta$, the parameter to be estimated and $w_{i}$, which are the unobservable random variables, assumed to be independently distributed and obtained by truncation of the normal distribution with zero mean and unknown variance $\sigma_{w}^{2}$, such that $\mathrm{u}_{\mathrm{i}} \geq 0$.

$$
u_{i}=z_{i}^{e} \delta+w_{i}
$$

The constant $\alpha$ in equations (2) and (3) and the parameters $\beta, \gamma$ and $\delta$ in equations (1) - (4) were estimated simultaneously, thereby excluding the possibility of producing biased results with the two-step approach (Wang and Schmidt 2002). The variables used for estimation of the production function and the determinants of inefficiency are presented in Table 1.

\section{Data and variables}

An unbalanced rotating panel of the FAS data provided by the Swedish Statistics Office for the period 2002-2012 was analysed. Every year, the Swedish FAS sample survey includes about 1000 randomly selected farms, based on a rotating scheme, meaning that some farms are dropped from the sample and are replaced by new farms. Farm participation in the survey is not compulsory, and the period for which farms are included in the sample is not limited. The FAS is the most comprehensive and standardised farm-level dataset at national level and is also used for completing the European Farm Accounting Data Network (FADN) submission. In the present study, data for farms specialising in dairy production were used. Farm selection was based on the relative importance/contribution of the milk revenue to total standard output of the enterprise, with a proportion of $2 / 3$ as a threshold. In total, 3578 observations representing 668 individual farms were included in the analysis. The dataset provided detailed information on farm outputs in value terms, use of inputs in terms of quantity and/or value, the amount of subsidybased payments received by the farmer, region/location and production details. Moreover, period-specific characteristics to capture the compensation effect of the rural development programme at regional level, over 20022006 and, after the changes in environmental payments implemented for Pillar II, for 2007-2013 can be observed.

To estimate the efficiency, one output and five input variables were used (Table 1). Output represented the: i) farm revenue excluding subsidies, obtained from the production and agricultural activities on the farms in the case of the PTE analysis and ii) farm revenue including subsidies, considering both the farm production value and the total Pillar II subsidies amount, in the case of the CTE analysis. The unit of measurement was Swedish Kronor (SEK), deflated with the respective national output price index, with 2005 as the base year. For example the revenue obtained from milk production was deflated with the national milk price index. Inputs were aggregated as follows: i) Total livestock units (LU), estimated following the standard computational procedure for aggregation of livestock from various species and age; ii) utilised agricultural area (UAA) in hectares, including both arable and grazing area; iii) labour, corresponding to the total labour input (family and hired) of the farm expressed in total working hours; iv) costs of materials included: total costs of seeds, fertilisers, crop protection, feed, energy (including electricity, and fuel use for heating and machinery, lubricants and water) and specific (veterinary) costs; v) capital costs represented by the total costs of capital use, including: depreciation, maintenance of buildings and 
machinery, rents and insurance. The inputs given in value units (material and capital costs) were measured in SEK, deflated with the respective national input price index (base year 2005). For example, costs of animal feed were deflated with the national price index for animal feed. Information on the national output price and input price index was obtained from the Swedish Board of Agriculture (Swedish Board of Agriculture 2015).

As this study was concerned with the compensatory effect of agricultural support payments (Pillar II) on farm efficiency, farm-specific characteristics expected to be influenced by the compensatory effect were included (Table 1). In the model, these characteristics represented the efficiency determinants classified into two groups: i) Region- and period-specific differences; and ii) output-reducing farm management production practices.

The Swedish FADN area division for agriculture and rural development at NUTS1 level and the regional division based on the distribution of environmental support across Sweden were used as region-specific characteristics. In addition, time period details were assigned to each NUTS1 region. In total, six dummies were constructed, corresponding to the main farming regions of Sweden (Region 1 - southern and central plains area, Region 2 - southern and central forest and valley area and Region 3 - northern Sweden), and two time periods (2002-2006 and 2007-2013). Farms belonging to the groups defined for the dummies were assigned " 1 ", or otherwise "0". Region 1 was assigned as a base region. Period-specific differences were included in order to capture the compensation effect of the rural development programme in the period 2002-2006 and, after the changes implemented for Pillar II, for 2007-2013. The regional division in Table 1, which is based on the distribution of environmental support across Sweden (in Swedish: stödområden för miljöersättningar), was assigned to show the environmental sensitivity of regions, and was represented by one scale variable ranging from 1-6, with 1 denoting the first-class, most sensitive regions in environmental terms, with a very large share of LFA and thus most supported, and 6 not environmentaly affected and no LFA at all.

Extensive farming is supported by the rural development programme and integrated into environmental management schemes aimed at integrated farm management, diversified production, lower livestock density and extensive land fertilisation and grazing management. In this study, the compensatory effects of the support payments were tested for seven output-reducing farm management production practices: organic production, low specialisation in milk production, livestock density, capital intensification, pasture availability, fertiliser use and pesticide use. Agri-environmental management practices associated with animal welfare, pasture management, forage production, crop rotation practices or pollination management are also of great importance for eligibility for Pillar II payments. However, as such information is not included in the FAS data, the subsidisation effect on these characteristics could not be studied.

In Table 1, 'organic farming' denotes farm involvement in organic farming practices; one dummy variable was constructed and assigned a value " 1 " for organic farms and " 0 " for conventional farms or farms in transition/mixed. With the dataset used, organic farming practices were applied on $14 \%$ of the farms included in the analysis. Farm specialisation in milk production was defined as share of milk revenue in agricultural revenue (Total farm revenue = Agricultural revenue + revenue from non-agricultural, entrepreneurial activities). Average estimated share of milk revenue in the agricultural revenue of the farms observed was $80 \%$. For the analysis, three dummies were defined: Specialisation 1 as a base variable for share < 80\%, specialisation 2 for share $80-90 \%$ and specialisation 3 for share $>90 \%$. Livestock density was calculated as the number of livestock units per unit farm area utilised (LU $\mathrm{ha}^{-1}$ ) with an average estimated livestock density of $1 \mathrm{LU} \mathrm{ha-1}{ }^{-1}$ including arable and grazing land. Three dummies were defined: density 1 as a base variable for farms having $<1$ ha $^{-1}$, density 2 for farms with livestock density of 1-1.5 LU ha-1 and density 3 for farms with livestock density $>1.5 \mathrm{ha}^{-1}$. Degree of capital intensification is an indication of the capital costs per livestock unit. Three dummies were selected: capital intensity 1 as a base, capital intensity 2 and capital intensity 3, corresponding to: < 5000, 5000-10000 and > 10000 SEK capital costs per livestock unit, respectively. The average estimated capital cost per livestock unit of the data sample included in the analysis was around 6099 SEK, corresponding to about 100 Euros. Pasture availability was defined as ratio of pasture land per unit grazing livestock, with an average estimated value of 0.18 ha $\mathrm{LU}^{-1}$. The use of fertilisers and pesticides was proxied as a cost in SEK, normalised per hectare. In the literature, continuous explanatory variables of inefficiency for the time trend (showing the change in TE over the period of observation), degree of specialisation, livestock density and capital intensity are common practice. In the present analysis, preference was given to categorical dummies allowing testing for the technically most efficient group (for example, for the level of specialisation three groups were defined: $<80 \%, 80-90 \%$ and $>90 \%$ ), and the most relevant policy scheme for the time period (i.e. 2002-2006 or 2007-2013) assigned to the NUTS regions. 
Descriptive statistics on the input-output variables used for estimation of the production function, the efficiency determinants expected to be influenced by the compensation effect and the three hypotheses tested are given in Table 1.

\begin{tabular}{|c|c|c|c|}
\hline Variable & Unit & Mean & SD \\
\hline \multicolumn{4}{|l|}{ Outputs } \\
\hline Revenue without subsidies & SEK & 1735608 & 2286596 \\
\hline Revenue with subsidies & SEK & 2184990 & 2652416 \\
\hline \multicolumn{4}{|l|}{ Inputs } \\
\hline Total livestock units & LU & 100 & 109 \\
\hline Total agricultural area & ha & 89 & 91 \\
\hline Total labour on the farm & hours & 4428 & 2810 \\
\hline Material costs & SEK & 658344 & 872447 \\
\hline Capital costs & SEK & 609984 & 734852 \\
\hline \multicolumn{4}{|c|}{ Efficiency determinants: region and period } \\
\hline Region 1: period 2002 to 2006 & $\begin{array}{l}\text { Dummy } \\
\text { (base) }\end{array}$ & 19.6 & 0.397 \\
\hline Region 2: period 2002 to 2006 & Dummy & 12.3 & 0.328 \\
\hline Region 3: period 2002 to 2006 & Dummy & 10.4 & 0.305 \\
\hline Region 1: period 2007 to 2012 & $\begin{array}{l}\text { Dummy } \\
\text { (base) }\end{array}$ & 26.3 & 0.441 \\
\hline Region 2: period 2007 to 2012 & Dummy & 18.0 & 0.384 \\
\hline Region 3: period 2007 to 2012 & Dummy & 13.4 & 0.341 \\
\hline $\begin{array}{l}\text { Environmental sensitivity of } \\
\text { regions }\end{array}$ & scale 1-6 & 4.4 & 1.491 \\
\hline \multicolumn{4}{|c|}{ Efficiency determinants: output-reducing farm management } \\
\hline Organic farming & Dummy & 14.4 & 0.352 \\
\hline Specialisation < 80\% & $\begin{array}{l}\text { Dummy } \\
\text { (base) }\end{array}$ & 30.0 & 0.459 \\
\hline Specialisation 80-90\% & Dummy & 52.4 & 0.499 \\
\hline Specialisation $>90 \%$ & Dummy & 17.5 & 0.380 \\
\hline Livestock density $<1$ LU ha-1 & $\begin{array}{l}\text { Dummy } \\
\text { (base) }\end{array}$ & 60.0 & 0.490 \\
\hline Livestock density 1-1.5 LU ha-1 & Dummy & 29.0 & 0.454 \\
\hline Livestock density > 1.5 LU ha-1 & Dummy & 11.0 & 0.312 \\
\hline Capital intensity $<5000$ SEK $^{-1} \mathrm{LU}$ & $\begin{array}{l}\text { Dummy } \\
\text { (base) }\end{array}$ & 38.2 & 0.486 \\
\hline $\begin{array}{l}\text { Capital intensity 5000-10000 } \\
\text { SEK LU }{ }^{-1}\end{array}$ & Dummy & 52.5 & 0.499 \\
\hline Capital intensity > 10000 SEK LU $^{-1}$ & Dummy & 9.3 & 0.290 \\
\hline Pasture availability & ha $\mathrm{LU}^{-1}$ & 17.7 & 0.298 \\
\hline Fertiliser & SEK ha ${ }^{-1}$ & 6.8 & 6.464 \\
\hline Pesticides & SEK ha ${ }^{-1}$ & 0.9 & 1.450 \\
\hline
\end{tabular}

\section{Hypotheses}

Given this conceptual framework, the farm-specific characteristics anticipated to be related to the compensatory effect of the support payments and findings in the literature review, three hypotheses were formulated (Table 1). 
Hypothesis 1 (H1): Support payments are provided to decrease the difference in revenue generated through operating in an agriculture-sensitive region and application of output-reducing farm management practices (EC 2016), and thus average farm efficiency can be expected to be improved. However, it needs to be emphasised that the mean estimated CTE will exceed the mean estimated PTE only in cases where the support is properly distributed. Inappropriate support distribution can even increase the gap between farmers, making the farms with low efficiency even less efficient relative to the other producers.

Hypothesis $2(\mathrm{H} 2)$ : Without farm support, farming in areas with environmental/infrastructural constraints and extensive farming practices (such as organic farming and a low level of specialisation, livestock density, capital intensity, pasture availability) is less efficient than farming in regions with good agricultural potential and intensive farming conditions (such as in Sipiläinen et al. 2009, Manevska-Tasevska et al. 2014).

Hypothesis 3 (H3): Support payments compensate for environmental/regional differences originating from lower regional potential for agriculture and application of output-reducing farm management practices; a statistically significant influence of these characteristics is thus not expected. In terms of compensating for costs, Sipiläinen and Huhtala (2013) claim that it is commonly accepted that agri-environmental policies compensate farmers for the costs of conservation measures.

\section{Results and discussion Sample mean of pure and compensated technical efficiency}

The mean estimated PTE and CTE of the sample and the sub-samples representing the selected regional specifics and output-reducing farm management practices, as well as the relative contribution of the subsidy payment to the CTE, are given in Table 2. According to the results, the average sample-estimated PTE is $89 \%$ (Fig. 1a) and CTE is $94 \%$ (Fig. 1b). When support payments are considered, the relative increase (CTE/PTE-1) in TE is $6 \%$, with a noticeable reduction in the number of farms with TE below $80 \%$ (compare Figs. $1 \mathrm{a}$ and $1 \mathrm{~b}$ ). Details on the production function parameters and elasticities at the sample mean are provided in Table A1 and Table A2 in Appendix 1 and 2 , respectively.

a)

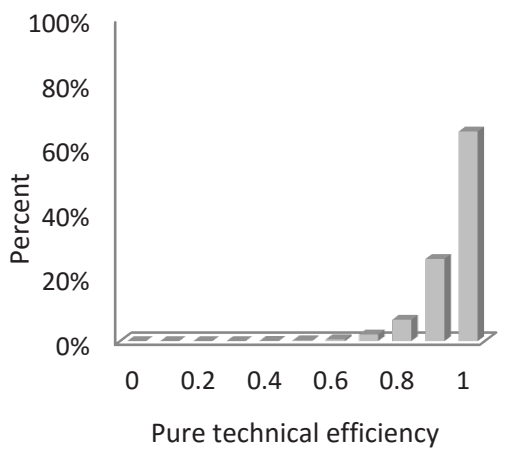

b)

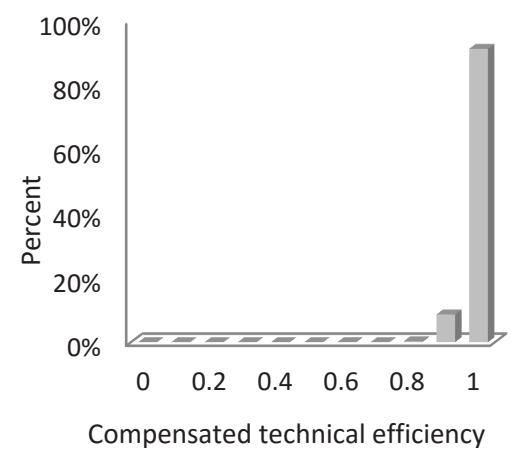

Fig. 1. Distributional graphs of (a) pure technical efficiency and (b) compensated technical efficiency

The results confirmed hypothesis ( $\mathrm{H} 1$ ), i.e. support payments decreased the difference in revenue generated through output-reducing regional characteristics and output-reducing managerial practices. Farm efficiency on average level was improved, satisfying the condition that CTE $\geq$ PTE. One can argue that this result is an obvious outcome of providing support payments. However, inappropriate support distribution can even increase the gap between farmers, making the farms with low efficiency even less efficient relative to the other producers.

Direct comparison of TEs between countries is not appropriate, primarily due to the fact that the scores represent the heterogeneity of the sample analysed, but also due to different model setups. However, just as a guide, the TE coefficient values obtained for the PTE are in line with findings obtained for dairy farms in other EU member countries (Barnes and Revoredo-Giha 2011, Latruffe et al. 2012). Older studies using data on Swedish dairy farms (1998-2003) have found slightly lower values, with Zhu et al. (2008) reporting 79\%, Sipiläinen et al. (2008) 80\% and Hansson and Ohlmer (2008) 86\%.

As can be seen, the average estimated TEs and the relative improvement differed between regions and periods and with the use of output-reducing management practices, see Table 2. In the case of PTE, when the support payments were not considered, farms located in northern Sweden (Region 3) and the central valley forest area 
(Region 2) were the least efficient, with average efficiency of $80 \%$ and $90 \%$, respectively. Farms located on the southern plains and in central areas around major cities (Region 1) were the most efficient, with average efficiency of approximately 94\%. Indeed, Region 1 is recognised as the most suitable for agricultural production in Sweden, benefiting from a good growing climate, good soil quality and well-developed infrastructural and processing facilities. When the Pillar II support payments were considered as part of agricultural output (CTE), differences in TEs between farms located in different regions decreased noticeably. The average estimated CTE achieved by Swedish dairy producers in all regions in the period 2002-1012 was then 95\%. However, Region 2 appeared to be slightly less efficient (93\%) in 2007-2012, whereas in Region 3 over-compensation (99\%) possibly occurred in 2002-2006 (Table 2).

Table 2. Mean pure and compensated technical efficiency and (relative change), ratio (CTE/PTE)-1

\begin{tabular}{|c|c|c|c|}
\hline & $\begin{array}{c}\text { Mean } \\
\text { PTE }\end{array}$ & $\begin{array}{l}\text { Mean } \\
\text { CTE }\end{array}$ & $\begin{array}{c}\text { Relative change } \\
\text { (mean CTE/mean } \\
\text { PTE)-1 }\end{array}$ \\
\hline TE of the sample & $89 \%$ & $95 \%$ & $6 \%$ \\
\hline \multicolumn{4}{|l|}{ Regional potential } \\
\hline $\begin{array}{l}\text { Region 1: period } 2002 \text { to } \\
2006\end{array}$ & $94 \%$ & $95 \%$ & $1 \%$ \\
\hline $\begin{array}{l}\text { Region 1: period } 2007 \text { to } \\
2012\end{array}$ & $94 \%$ & $95 \%$ & $1 \%$ \\
\hline $\begin{array}{l}\text { Region 2: period } 2002 \text { to } \\
2006\end{array}$ & $89 \%$ & $94 \%$ & $6 \%$ \\
\hline $\begin{array}{l}\text { Region 2: period } 2007 \text { to } \\
2012\end{array}$ & $89 \%$ & $93 \%$ & $4 \%$ \\
\hline $\begin{array}{l}\text { Region 3: period } 2002 \text { to } \\
2006\end{array}$ & $81 \%$ & $99 \%$ & $23 \%$ \\
\hline $\begin{array}{l}\text { Region 3: period } 2007 \text { to } \\
2012\end{array}$ & $79 \%$ & $96 \%$ & $22 \%$ \\
\hline \multicolumn{4}{|l|}{$\begin{array}{l}\text { Output-reducing farm } \\
\text { management }\end{array}$} \\
\hline Conventional farms & $90 \%$ & $94 \%$ & $4 \%$ \\
\hline Organic farms & $86 \%$ & $99 \%$ & $15 \%$ \\
\hline Specialisation $<80 \%$ & $89 \%$ & $95 \%$ & $7 \%$ \\
\hline Specialisation $80-90 \%$ & $90 \%$ & $96 \%$ & $6 \%$ \\
\hline Specialisation > 90\% & $84 \%$ & $94 \%$ & $12 \%$ \\
\hline $\begin{array}{l}\text { Livestock density < } 1 \text { LU } \\
\text { ha }^{-1}\end{array}$ & $87 \%$ & $94 \%$ & $8 \%$ \\
\hline $\begin{array}{l}\text { Livestock density 1-1.5 LU } \\
\text { ha }^{-1}\end{array}$ & $90 \%$ & $95 \%$ & $6 \%$ \\
\hline Livestock density > $1.5 \mathrm{ha}^{-1}$ & $96 \%$ & $98 \%$ & $2 \%$ \\
\hline $\begin{array}{l}\text { Capital intensity }<5000 \\
\text { SEK LU }\end{array}$ & $90 \%$ & $95 \%$ & $6 \%$ \\
\hline $\begin{array}{l}\text { Capital intensity 5000- } \\
10000 \text { SEK LU }^{-1}\end{array}$ & $89 \%$ & $95 \%$ & $7 \%$ \\
\hline $\begin{array}{l}\text { Capital intensity > } 10000 \\
\text { SEK LU }\end{array}$ & $86 \%$ & $95 \%$ & $10 \%$ \\
\hline $\begin{array}{l}\text { Pasture availability } 0-020 \\
\text { ha } \mathrm{LU}^{-1}\end{array}$ & $88 \%$ & $95 \%$ & $8 \%$ \\
\hline $\begin{array}{l}\text { Pasture availability } 0.21- \\
0.40 \text { ha LU }^{-1}\end{array}$ & $91 \%$ & $95 \%$ & $4 \%$ \\
\hline $\begin{array}{l}\text { Pasture availability } 0.41- \\
0.60 \text { ha LU }^{-1}\end{array}$ & $90 \%$ & $94 \%$ & $4 \%$ \\
\hline $\begin{array}{l}\text { Pasture availability } 0.61- \\
0.80 \text { ha LU }^{-1}\end{array}$ & $89 \%$ & $94 \%$ & $6 \%$ \\
\hline $\begin{array}{l}\text { Pasture availability } 0.081- \\
1.00 \text { ha }^{-1 U^{-1}}\end{array}$ & $89 \%$ & $95 \%$ & $7 \%$ \\
\hline $\begin{array}{l}\text { Pasture availability 1.01- } \\
3.00 \mathrm{ha} \mathrm{LU}^{-1}\end{array}$ & $84 \%$ & $96 \%$ & $14 \%$ \\
\hline $\begin{array}{l}\text { Pasture availability }>3.00 \\
\text { ha } \mathrm{LU}^{-1}\end{array}$ & $77 \%$ & $99 \%$ & $29 \%$ \\
\hline
\end{tabular}

Values in column 3 represent the relative change in the TE, after the subsidy distribution (CTE/PTE)-1. 
In terms of output-reducing farm management practices, the lowest estimated mean PTE was found for organic farms and farms with lower specialisation in milk production $<80 \%$, low livestock density $\left(<1 \mathrm{LU}^{\left.\mathrm{h} \mathrm{C}^{-1}\right)}\right.$ and high pasture availability $\left(>3\right.$ ha $\left.\mathrm{LU}^{-1}\right)$. Table 2 provides evidence supporting hypothesis $\mathrm{H} 2$, which focused on PTE and proposed that without the compensatory support payments, dairy farms located in areas with low agricultural potential, organic farms and extensive farming systems (characterised by low specialisation, capital intensity, livestock density and concentrate-based feed) would be less efficient. However, there were also signs of 'over-capitalisation' and 'over-specialisation', as low mean PTE was obtained for farms with high capital intensity (> 10000 SEK LU'-1) and high specialisation (>90\%).

The relative improvements in TE generated by support payments distributed to farmers were highest for the least efficient farms. For example, the average relative change in mean PTE and CTE was: $1 \%$ for both periods (20022006 and 2007-2012) for Region 1; 6\% (2002-2006) and 4\% (2007-2012) for Region 2; and 23\% (2002-2006) and $22 \%$ (2007-2012) for Region 3. Furthermore, the highest relative change (where CTE/PTE > = 10\%) was found for organic (15\%) and pasture-intensive farms (with $14 \%$ of farms having $1-3$ ha $\mathrm{LU}^{-1}$ and $29 \%>3 \mathrm{ha} \mathrm{LU}^{-1}$ ). With the compensation payments considered (CTE), organic and pasture-based farming (pasture availability $>3$ ha $L U^{-1}$ ) became equally or even more efficient than conventional farms and farms with less pasture per livestock unit. However, the TE of the farms with low livestock density did not improve sufficiently, and higher livestock density farms remained more efficient. The results presented above represent the average PTE and CTE of the sample and the mean of sub-samples of farms with selected characteristics. The influence of the selected efficiency determinants was also tested statistically, as described in the following section.

\section{Determinants of pure and compensated technical efficiency}

The results of the regression analysis, in which the influence of the selected regional and output-reducing management farm practices was tested for PTE and CTE, are shown in Table 3. A correlation matrix of efficiency determinants containing correlation coefficients and significance level (*) is presented in Table A3 in Appendix 3. Given the results, no correlation between the efficiency determinants was found.

The parameter estimates provided for PTE and CTE indicate the direction of the effects of the selected explanatory variables (although the magnitude of the farms does not indicate the size of the inefficiency effect). Since an inefficiency model was applied, a positive sign indicates a negative influence on the TE and a negative sign a positive influence. Without the subsidies considered (PTE), the findings confirm the existence of lower efficiency on organic and pasture-based farms and on farms located in the central valley (Region 2) and the northern region (Region 3) over the whole study period. Livestock density and capital intensity were also found to drive the PTE of the farms, with farms having $>5000 \mathrm{SEK} \mathrm{LU}^{-1}$ and $>1.5 \mathrm{LU} \mathrm{ha}^{-1}$ being more efficient than farms with low capital intensity $\left(<5000\right.$ SEK LU $\left.^{-1}\right)$ and low livestock density $\left(<1 \mathrm{LU} \mathrm{ha}^{-1}\right)$. However, when Pillar II subsidies were included in the farm revenue (CTE), the advantage of conventional over organic, high capital over low capital intensity and specialised $(\geq 80 \%$ ) over less specialised $(<80 \%)$ appeared to diminish. Farms with very high specialisation in milk production (>90\%) then became significantly less efficient and farms with livestock density $>1 \mathrm{LU}^{-1} \mathrm{ha}^{-1}$ were more likely to be more efficient. A negative impact of intensive use of chemicals (fertilisers and pesticides) was found for both PTE and CTE. Our third hypothesis (H3) stated that support payments would compensate for lower regional potential for agriculture and use of output-reducing farm management practices. However, the results showed that the compensatory effect on farm outputs was only partial (Table 3). For example, farms located in the southern and central forest and valley areas (Region 2) received insufficient subsidisation, especially over the first period (2002-2007), as did farms with low livestock density $\left(<1\right.$ LU ha $\left.^{-1}\right)$. However, satisfactory compensation was awarded to organic and low capital intensity farms. 
Table 3. Summary of the results of the inefficiency effect model for pure and compensated technical efficiency (TE)

\begin{tabular}{|c|c|c|c|c|}
\hline Efficiency determinant & PTE coefficient & $p>z$ & $\begin{array}{c}\text { CTE } \\
\text { coefficient }\end{array}$ & $p>z$ \\
\hline \multicolumn{5}{|l|}{ Regional potential } \\
\hline \multicolumn{5}{|l|}{$\begin{array}{l}\text { Region 1: period } 2002 \text { to } \\
2006 \text { (base) }\end{array}$} \\
\hline $\begin{array}{l}\text { Region 2: period } 2002 \text { to } \\
2006\end{array}$ & 0.7570 & $* * *$ & 0.4251 & \\
\hline $\begin{array}{l}\text { Region 3: period } 2002 \text { to } \\
2006\end{array}$ & 0.9242 & $* * *$ & -4.0409 & \\
\hline \multicolumn{5}{|l|}{$\begin{array}{l}\text { Region 1: period } 2007 \text { to } \\
2012 \text { (base) }\end{array}$} \\
\hline $\begin{array}{l}\text { Region 2: period } 2007 \text { to } \\
2012\end{array}$ & 0.8117 & $* * *$ & 0.9835 & $* * *$ \\
\hline $\begin{array}{l}\text { Region 3: period } 2007 \text { to } \\
2012\end{array}$ & 1.2806 & $* * *$ & 0.8178 & \\
\hline $\begin{array}{l}\text { Environmental sensitivity of } \\
\text { regions scale 1-6; for } 1 \text { most } \\
\text { affected, } 6 \text { not affected } \\
\text { at all }\end{array}$ & -0.4851 & $* * *$ & 0.1726 & \\
\hline \multicolumn{5}{|l|}{$\begin{array}{l}\text { Output-reducing farm } \\
\text { management }\end{array}$} \\
\hline Organic farming & 0.5970 & $* * *$ & -2.3408 & \\
\hline \multicolumn{5}{|l|}{ Specialisation $<80 \%$ (base) } \\
\hline Specialisation $80-90 \%$ & -0.5343 & $* * *$ & -0.1827 & \\
\hline Specialisation > 90\% & 0.2391 & & 0.9131 & $* * *$ \\
\hline \multicolumn{5}{|l|}{$\begin{array}{l}\text { Livestock density <1 LU } \\
\text { ha }^{-1} \text { (base) }\end{array}$} \\
\hline $\begin{array}{l}\text { Livestock density 1-1.5 } \\
\text { LU ha }^{-1}\end{array}$ & -0.2328 & & -.8350 & $* * *$ \\
\hline $\begin{array}{l}\text { Livestock density }>1.5 \mathrm{LU} \\
\mathrm{ha}^{-1}\end{array}$ & -1.4508 & $* * *$ & -2.8662 & $* * *$ \\
\hline $\begin{array}{l}\text { Capital intensity 5000- } \\
10000 \text { SEK LU-1 }\end{array}$ & -0.3689 & $* * *$ & -0.2367 & \\
\hline $\begin{array}{l}\text { Capital intensity }>10000 \\
\text { SEK LU-1 }\end{array}$ & -0.3812 & $*$ & -0.5276 & \\
\hline Pasture availability ha $\mathrm{LU}^{-1}$ & 0.4304 & $* *$ & -0.7805 & \\
\hline Fertiliser use SEK ha-1 & 0.0557 & $* * *$ & 0.0949 & $* * *$ \\
\hline Pesticide use SEK ha- ${ }^{-1}$ & 0.1310 & $* * *$ & 0.1955 & $* * *$ \\
\hline Insig2v constant & -3.3272 & $* * *$ & -3.4638 & $* * *$ \\
\hline Insig2u constant & -2.4453 & $* * *$ & -6.6491 & $* * *$ \\
\hline
\end{tabular}

Positive sign of the PTE and CTE coefficients is an indication of a negative influence on TE. ${ }^{* * *}=$ statistically significant at $1 \%,{ }^{* *}=$ statistically significant at $5 \%,{ }^{*}=$ statistically significant at $10 \%$

\section{Conclusions}

This study analysed the success of EU agricultural support in eliminating the negative influences of differing regional potential for agriculture and output-reducing farm management practices on agricultural output on Swedish dairy farms. The compensation effect was evaluated by a comparative analysis observing the 'pure' TE (estimated without Pillar II subsidies included in total farm revenue) and 'compensated' TE (estimated with Pillar II subsidies included in total farm revenue) of the farms. In the analysis, PTE was taken as a benchmark for the prevailing production conditions and CTE as a proxy indicator of the compensation effect. 
The results confirmed previous findings that farms subjected to agri-environmental pressure, such as regional disadvantages and/or output-reducing management practices, are generally less efficient. After considering the Pillar II support payments distributed to farmers, the analysis showed that in Sweden, these payments have not fully succeeded in meeting regional needs. Difficulties in the ability of dairy producers to generate sufficiently high output/revenue were apparent for the southern and central forest and valley areas (Region 2), particularly in the period 2007-2012. Furthermore, Pillar II agricultural support was found to compensate only partially for outputreducing farm management practices: compensation was satisfactory for organic and low capital intensity farms, but farms with low livestock density $\left(<1 \mathrm{LU} \mathrm{ha}^{-1}\right)$ were not sufficiently compensated. From a practical point of view, the sustainability/existence of such farms in the long run can thus be considered uncertain. From a policy point of view, the recently implemented (since 2015) adjustments to the support distribution are justified and greater benefit of the new support payment allocation schemes can be expected.

However, the environmental and cultural benefits arising from agri-environmental subsidies should not be underestimated. The scale of such effects was not determined in this study and thus the overall impact of the farm payments is larger and more comprehensive than shown here. More research on this issue is needed. Further research including wider sets of EU countries is also needed to fully analyse the success of environmental agricultural support in compensating farmers for differences in the regional potential for agriculture and for use of output-reducing farm management practices across the EU.

This study attempted to draw conclusions about the compensatory effect of the subsidies on the efficiency of agricultural output generation at national level, but the limitations of FADN considering farm threshold size demanded caution. In addition, the regional division used in the study corresponded to the NUTS1 division, with three regions (Region 1 - southern and central plain areas, Region 2 - southern and central forest and valley areas and Region 3 - northern Sweden). Within-region differences at NUTS2 level (six regions) and even more at NUTS3 level (21 region) may exist, but could not be identified here.

The EU CAP is designed to support farming that promotes balanced regional development and compensates for production conditions that restrain agricultural production across all of Europe's rural areas. This study represents the first attempt at a comparative efficiency analysis observing 'pure' and 'compensated' TE as a proxy for the compensation effect. The efficiency literature draws policy-related conclusion/recommendations based on analyses with different model set-ups, where the subsidy "is" or "is not" considered part of farm output. This study used a single data set and compared the gaps between the TEs obtained with both approaches. The results have policy implications for farm technical performance and thus represent direct input to future policy recommendations for support allocation.

\section{Acknowledgements}

We thank the two anonymous reviewers, Mark Brady and Helena Hansson for their constructive comments and suggestions on earlier versions of the manuscript.

\section{References}

Acs, S., Berentsen, P., Huirne, R. \& Van Asseldonk, M. 2009. Effect of yield and price risk on conversion from conventional to organic farming. Australian Journal of Agricultural and Resource Economics 53: 393-411.

Aigner, D., Lovell, C.A.K. \& Schmidt, P. 1977. Formulation and estimation of stochastic frontier production function models. Journal of Econometrics 6: 21-37.

Alvarez, A. \& Arias, C. 2004. Technical efficiency and farm size: A conditional analysis. Agricultural Economics 30: $241-250$.

Alvarez, A., Del Corral, J., Solís, D. \& Pérez, J. 2008. Does intensification improve the economic efficiency of dairy farms? Journal of Dairy Science 91: 3693-3698.

Barnes, A. P. 2008. Technical efficiency estimates of Scottish agriculture: A Note. Journal of Agricultural Economics 59: 370-376.

Barnes, A.P. 2006. Does multi-functionality affect technical efficiency? A non-parametric analysis of the Scottish dairy industry. Journal of Environmental Management 80: 287-294.

Barnes, A.P., Hansson, H., Manevska-Tasevska, G., Shrestha, S.S. \& Thomson, S.G. 2015. The influence of diversification on longterm viability of the agricultural sector. Land Use Policy 49: 404-412.

Barnes, A.P. \& Revoredo-Giha, C. 2011. A metafrontier analysis of technical efficiency of selected European agricultures. In: Land Economy Environment Working Paper Series, No. 55. Scottish Agricultural College (SAC) Research Division, Edinburgh, Scotland. 14 p.

Battese, G.E. \& Coelli, T.J. 1995. A model for technical inefficiency effects in a stochastic frontier production function for panel data. Empirical Economics 20: 325-332. 
Brady, M., Höjgård, S., Johansson, H., Jansik, C., Kaspersson, E., Lehtonen, H., Niemi, J., Pietola, K., Puurunen, M., Rabinowicz, E. \& Sipiläinen, T. 2007. An evaluation on the impact of Nordic aid schemes in northern Finland and Sweden. The report prepared by Agrifood Research Finland (MTT) and the Swedish Institute for Food and Agricultural Economics (SLI) for DG Agriculture and Rural Development and DG Economic Analyses and Evaluation: 224 p. http://ec.europa.eu/agriculture/eval/reports/nordic/fulltext_en.pdf.

Breustedt, G., Latacz-Lohmann, U. \& Tiedemann, T. 2011. Organic or conventional? Optimal dairy farming technology under the EU milk quota system and organic subsidies. Food Policy 36: 223-229.

Coelli, T.J., Rao, D.S.P., O'Donnell, C.J. \& Battese, G.E. 2005. An introduction to efficiency and productivity analysis. New York, USA: Springer Science+Business Media, LLC. 349 p.

Dawson, P. 1987. Farm-specific technical efficiency in the England and Wales dairy sector. European Review of Agricultural Economics 14: 383-394.

EC 2009. Rural development (2000-2006) in EU farms. European Commission, DG Agriculture and Rural Development, Directorate L3 Microeconomic Analysis of EU agricultural holdings, Brussels, Belgium, July, 2009. 49 p.

EC 2013. Facts and figures on organic agriculture in the European Union. European Commission, DG Agriculture and Rural Development, Unit Economic Analysis of EU Agriculture, Brussels, Belgium, May, 2013. 46 p.

EC 2016. Glossary of terms related to the Common Agricultural Policy. European Commission, Agriculture and Rural Development. http://ec.europa.eu/agriculture/glossary/index_en.htm. Accessed 12 February 2016.

Fried, H.O., Lovell, C.K. \& Schmidt, S.S. 2008. The measurement of productive efficiency and productivity growth. New York, USA: Oxford University Press. 638 p.

Hadley, D. 2006. Patterns in technical efficiency and technical change at the farm-level in England and Wales, 1982-2002. Journal of Agricultural Economics 57: 81-100.

Hansson, H. 2007. Strategy factors as drivers and restraints on dairy farm performance: Evidence from Sweden. Agricultural Systems 94: 726-737.

Hansson, H. \& Ohlmer, B. 2008. The effect of operational managerial practices on economic, technical and allocative efficiency at Swedish dairy farms. Livestock Science 118: 34-43.

Henningsen, A. \& Henning, C.H. 2009. Imposing regional monotonicity on translog stochastic production frontiers with a simple three-step procedure. Journal of Productivity Analysis 32: 217-229.

Kumbhakar, S.C. \& Heshmati, A. 1995. Efficiency Measurement in Swedish Dairy Farms: An Application of Rotating Panel Data, 1976-88. American Journal of Agricultural Economics 77: 660-674.

Kumbhakar, S.C. \& Lien, G. 2010. Impact of subsidies on farm productivity and efficiency. In: Ball, V.E., Fanfani, R., Gutierrez, L. (Eds.). The economic impact of public support to agriculture. New York, USA: Springer. p. 109-124.

Kumbhakar, S.C., Wang, H.-J. \& Horncastle, A. 2015. A practitioner's guide to stochastic frontier analysis using Stata. New York, USA: Cambridge University Press. 374 p.

Latruffe, L., Bravo-Ureta, B.E., Moreira, V.H., Desjeux, Y. \& Dupraz, P. 2012. Productivity and subsidies in the European Union: An analysis for dairy farms using input distance frontiers. In: International Association of Agricultural Economists (IAAE) Triennial Conference August 18-24, 2012. Foz do Iguacu, Brazil. http://ageconsearch.umn.edu/bitstream/126846/2/LatruffeEtAl.pdf.

Latruffe, L. \& Nauges, C. 2013. Technical efficiency and conversion to organic farming: the case of France. European Review of Agricultural Economics 41: 227-253.

Manevska-Tasevska, G., Hansson, H. \& Rabinowicz, E. 2014. Input saving possibilities and practices contributing to more efficient beef production in Sweden. Agricultural and Food Science 23: 118-134.

McCloud, N., \& Kumbhakar, S. C. 2008. Do subsidies drive productivity? A cross-country analysis of Nordic dairy farms. Advances in Econometrics 23: 245-274.

Meeusen, W. \& Broeck, J.v.D. 1977. Efficiency estimation from Cobb-Douglas production functions with composed error. International Economic Review 18: 435-444.

Parmeter, C.F. \& Kumbhakar, S.C. 2014. Efficiency Analysis: A primer on recent advances. Foundations and Trends (R) in Econometrics 7: 191-385.

Prager, K. 2015. Agri-environmental collaboratives for landscape management in Europe. Current Opinion in Environmental Sustainability 12: 59-66.

Rasmussen, S. 2011. Data for analysing productivity change in Danish Agriculture 1990-2007. Institute of Food and Resource Economic, FOI Documentation, No. 1, Vol. 2011. University of Copenhagen. 47 p.

Sauer, J., Frohberg, K. \& Hockmann, H. 2006. Stochastic efficiency measurement: the curse of theoretical consistency. Journal of Applied Economics 9: 139.

Sipiläinen, T. \& Huhtala, A. 2013. Opportunity costs of providing crop diversity in organic and conventional farming: would targeted environmental policies make economic sense? European Review of Agricultural Economics 40: 441-462.

Sipiläinen, T., Kortelainen, M., Ovaska, S. \& Ryhänen, M. 2009. Performance of Finnish dairy farms and its determinants: A comparison of parametric, semiparametric, and nonparametric methods. Food Economics - Acta Agriculturae Scandinavica, Section C 6: 173-184.

Sipiläinen, T., Kuosmanen, T. \& Kumbhakar, S.C. 2008. Measuring productivity differentials - An application to milk production in Nordic countries. In: European Association of Agricultural Economists. International Congress, August 26-29, 2008, Ghent, Belgium. Contributed Paper No. 44277.

Statistics Sweden 2014. Jordbruksstatistisk årsbok 2014 kapitel 11: Ekologisk produktion. Örebro: SCB. 403 p.

Swedish Board of Agriculture 2015. Jordbruksverkets statistikdatabas. Priser och prisindex. Accessed 10 February 2015. (in Swedish). 
Tilman, D., Cassman, K.G., Matson, P.A., Naylor, R. \& Polasky, S. 2002. Agricultural sustainability and intensive production practices. Nature 418: 671-677.

Wang, H.J. \& Schmidt, P. 2002. One-step and two-step estimation of the effects of exogenous variables on technical efficiency levels. Journal of Productivity Analysis 18: 129-144.

Wilson, P., Hadley, D., Ramsden, S. \& Kaltsas, I. 1998. Measuring and explaining technical efficiency in UK potato production. Journal of Agricultural Economics 49: 294-305.

Zhengfei, G. \& Lansink, A.O. 2006. The source of productivity growth in Dutch agriculture: a perspective from finance. American Journal of Agricultural Economics 88: 644-656.

Zhu, X., Demeter, R.M. \& Lansink, A.O. 2008. Competitiveness of dairy farms in three countries: the role of CAP subsidies. In: European Association of Agricultural Economists. 12th Congress of the European Association of Agricultural Economists Gent, Belgium. Contributed Paper No. 44143. http://ageconsearch.umn.edu/handle/44143. 


\section{Appendix 1}

Table A1. Stochastic frontier production function parameters estimated for the pure technical efficiency (PTE) model and the compensated technical efficiency (CTE) model

\begin{tabular}{|c|c|c|c|c|}
\hline & \multicolumn{2}{|c|}{ PTE model } & \multicolumn{2}{|c|}{ CTE model } \\
\hline & $\begin{array}{c}\text { PTE } \\
\text { coefficient }\end{array}$ & $p>z$ & CTE coefficient & $p>z$ \\
\hline $\log \left(X_{1}\right)$ : livestock units & -1.0321 & $*$ & -0.4101 & \\
\hline $\log \left(X_{2}\right)$ : area & 1.0125 & $* * *$ & 1.595 & $* * *$ \\
\hline $\log \left(X_{3}\right)$ : labour & -0.0684 & & -0.0693 & \\
\hline $\log \left(X_{4}\right)$ : materials & 1.4110 & $* * *$ & 0.0106 & \\
\hline $\log \left(X_{5}\right)$ : capital & -0.2501 & & -0.0605 & \\
\hline $0.5 \times\left[\log \left(X_{1}\right]^{2}\right.$ : livestock $x$ livestock & -0.1803 & $* * *$ & -0.1492 & $* * *$ \\
\hline $0.5 \times\left[\log \left(X_{2}\right)\right]^{2}:$ area $\times$ area & -0.0664 & $* * *$ & -0.0108 & \\
\hline $0.5 \times\left[\log \left(\mathrm{X}_{3}\right)\right]^{2}:$ labour $\times$ labour & 0.0296 & $* * *$ & 0.0256 & $* * *$ \\
\hline $\begin{array}{l}0.5 \times\left[\log \left(X_{4}\right)\right]^{2}: \text { materials } \times \\
\text { materials }\end{array}$ & 0.0371 & & 0.0930 & $* * *$ \\
\hline $0.5 \times\left[\log \left(\mathrm{X}_{5}\right)\right]^{2}:$ capital $\times$ capital & 0.0906 & $* * *$ & 0.0673 & $* * *$ \\
\hline $\log \left(X_{1}\right) \times \log \left(X_{2}\right)$ : livestock $x$ area & 0.1816 & $* * *$ & 0.1689 & $* * *$ \\
\hline $\log \left(X_{1}\right) \times \log \left(X_{3}\right)$ : livestock $\times$ labour & -0.0012 & & -0.0186 & \\
\hline $\begin{array}{l}\log \left(X_{1}\right) \times \log \left(X_{4}\right) \text { : livestock } x \\
\text { materials }\end{array}$ & 0.1886 & $* * *$ & 0.0954 & $* *$ \\
\hline $\log \left(X_{1}\right) \times \log \left(X_{5}\right)$ : livestock $x$ capital & -0.0245 & & 0.0080 & \\
\hline $\log \left(\mathrm{X}_{2}\right) \times \log \left(\mathrm{X}_{3}\right)$ : area $\times$ labour & 0.0159 & & 0.0158 & \\
\hline $\log \left(X_{2}\right) \times \log \left(X_{4}\right)$ : area $\times$ materials & -0.1294 & $* * *$ & -0.1803 & $* * *$ \\
\hline $\log \left(X_{2}\right) \times \log \left(X_{5}\right):$ area $\times$ capital & 0.0252 & & 0.0086 & \\
\hline $\begin{array}{l}\log \left(X_{3}\right) \times \log \left(X_{4}\right) \text { : labour } \times \\
\text { materials }\end{array}$ & -0.0291 & & -0.0120 & \\
\hline $\log \left(X_{3}\right) \times \log \left(X_{5}\right)$ : labour $\times$ capital & -0.0017 & & -0.0088 & \\
\hline $\begin{array}{l}\log \left(X_{4}\right) \times \log \left(X_{5}\right) \text { : materials } \times \\
\text { capital }\end{array}$ & -0.1468 & $* * *$ & -0.1159 & $* * *$ \\
\hline Time & 0.0085 & * & 0.0333 & $* * *$ \\
\hline Time $^{2}$ & 0.0009 & $* *$ & -0.0012 & $* * *$ \\
\hline Constant & 1.3666 & & 6.9570 & $* * *$ \\
\hline Log likelihood & 442.5 & & 1019.5 & \\
\hline Wald chi2(22) & 51049.7 & & 63731.3 & \\
\hline Prob > chi2 & 0.0000 & $* * *$ & 0.0000 & $* * *$ \\
\hline
\end{tabular}




\begin{tabular}{|c|c|c|c|c|c|c|}
\hline \multicolumn{7}{|c|}{ Appendix 2} \\
\hline \multicolumn{7}{|c|}{$\begin{array}{l}\text { In a Translog production function where the log values of the input variables used in the production function are } \\
\text { not mean-centred, interpretation of elasticities of the coefficients is not straightforward. For that purpose, estima- } \\
\text { tion of the total elasticity of output with respect to each input at each data point is needed, where the conditions } \\
\text { of positivity and diminishing marginal productivity ( are expected to be satisfied (Henningsen and Henning 2009; } \\
\text { Sauer et al. 2006). However, several previous econometric applications have tended to show that flexible func- } \\
\text { tional forms such as the Translog function, when applied to frontier production functions, tend to violate the the- } \\
\text { oretical consistency conditions in a number of enterprise-specific studies (Barnes 2008; Sauer et al. 2006), mainly } \\
\text { as a consequence of multicollinearity (Dawson 1987), or even as a result of model misspecification (Henningsen } \\
\text { and Henning (2009), which used to be the main criticism of SPF models. However, when the measurement of ef- } \\
\text { ficiency is the main focus and the estimates of the production frontier parameters are not the primary interest, } \\
\text { it is rather the overall predictive power of the estimated function that is of greater importance (Dawson 1987). } \\
\text { Alternatively, although computational procedures for imposing monotonicity and concavity on Translog stochas- } \\
\text { tic production frontiers have been suggested to be used by some economists (e.g. Sauer et al. 2006, Henningsen } \\
\text { and Henning 2009), their implementation is quite demanding in terms of econometric estimation and in the sense } \\
\text { that the fulfilment of these theoretical conditions may lead to a rather restrictive production frontier domain. }\end{array}$} \\
\hline & \multicolumn{5}{|r|}{ CTE model } & \\
\hline & $\begin{array}{l}\text { Elasticity } \\
\text { estimate }\end{array}$ & $\begin{array}{l}\text { Standard } \\
\text { error }\end{array}$ & $\begin{array}{c}\text { Diminishing } \\
\text { marginal } \\
\text { productivity }\end{array}$ & $\begin{array}{l}\text { Elasticity } \\
\text { estimate }\end{array}$ & $\begin{array}{l}\text { Standard } \\
\text { error }\end{array}$ & $\begin{array}{c}\text { Diminishing } \\
\text { marginal } \\
\text { productivity }\end{array}$ \\
\hline \multicolumn{7}{|l|}{ PTE model } \\
\hline Total livestock units & 1.0820 & 0.1515 & -15.9253 & 0.8465 & 0.2290 & -61.0508 \\
\hline Total agricultural area & 0.2837 & 0.0755 & -58.46603 & 0.1684 & 0.0637 & -41.1329 \\
\hline $\begin{array}{l}\text { Total labour on the } \\
\text { farm }\end{array}$ & -0.01608 & 0.2496 & 0.0191 & -0.1399 & 0.2112 & 0.0206 \\
\hline Material costs & 0.0300 & 0.2804 & 0 & -0.7166 & 0.2436 & 0 \\
\hline Capital costs & -1.0060 & 0.2600 & 0 & -0.7040 & 0.2212 & 0 \\
\hline
\end{tabular}

As shown in Table A2, the positivity condition (as expressed by a positive value of each production elasticity) was satisfied at the sample mean point for the following inputs: livestock units and agricultural area for the PTE and CTE model specifications. On the other hand, the positivity condition was not satisfied by capital input at the sample mean point, while for labour and material inputs the respective production elasticities were not significantly different from zero in both model specifications. Looking at individual sample data points, an inspection of the computer results indicated that the positive condition was fully satisfied by the livestock unit and agricultural area inputs, while it was violated for the majority of the observations on labour (as in Wilson et al. 1998, Alvarez and Arias 2004) and capital costs (as in Kumbhakar and Heshmati 1995). These latter patterns occurred for both the PTE and CTE model specifications.

The condition for diminishing marginal products was satisfied at the sample mean for the livestock units and agricultural area, whereas for three other inputs (i.e. labour, capital and materials), the first-order derivative of the marginal productivity was marginally positive or equal to zero (Table A2). 


\section{Appendix 3}

\begin{tabular}{|c|c|c|c|c|c|c|c|c|c|c|c|c|c|c|}
\hline & 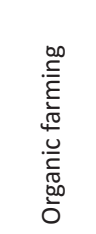 & 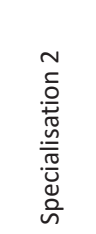 & 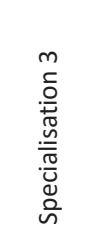 & 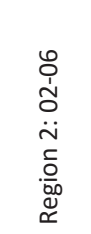 & 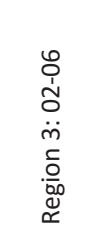 & 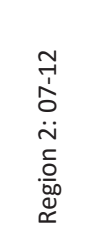 & 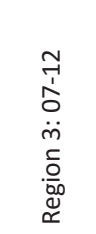 & 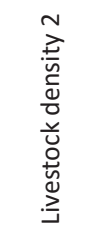 & 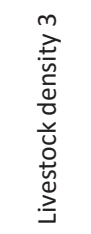 & 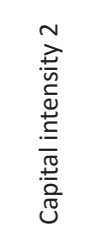 & 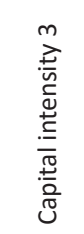 & 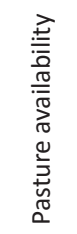 & 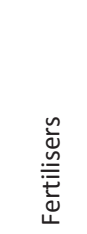 & 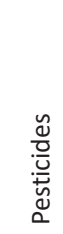 \\
\hline Organic farming & 1.00 & & & & & & & & & & & & & \\
\hline Specialisation 2 & 0.00 & 1.00 & & & & & & & & & & & & \\
\hline Specialisation 3 & $0.06^{*}$ & $-0.48^{*}$ & 1.00 & & & & & & & & & & & \\
\hline Region 2: 02-06 & $-0.06 *$ & -0.01 & $-0.04^{*}$ & 1.00 & & & & & & & & & & \\
\hline Region 3: 02-06 & $0.04^{*}$ & $-0.04^{*}$ & $0.15^{*}$ & $-0.13^{*}$ & 1.00 & & & & & & & & & \\
\hline Region 2: 07-12 & $-0.06^{*}$ & -0.02 & $-0.07^{*}$ & $-0.18^{*}$ & $-0.16^{*}$ & 1.00 & & & & & & & & \\
\hline Region 3: 07-12 & $0.16^{*}$ & 0.02 & $0.11^{*}$ & $-0.15^{*}$ & $-0.13^{*}$ & $-0.18^{*}$ & 1.00 & & & & & & & \\
\hline Livestock density 2 & $-0.13^{*}$ & $0.04^{*}$ & $-0.07^{*}$ & -0.02 & $-0.07^{*}$ & $0.06^{*}$ & $-0.05^{*}$ & 1.00 & & & & & & \\
\hline Livestock density 3 & $-0.12^{*}$ & 0.01 & -0.02 & $-0.07^{*}$ & $-0.12^{*}$ & -0.01 & $-0.13^{*}$ & $-0.22 *$ & 1.00 & & & & & \\
\hline Capital intensity 2 & $0.05^{*}$ & 0.01 & 0.03 & $-0.05^{*}$ & 0.00 & $0.04^{*}$ & 0.02 & $-0.08^{*}$ & $-0.05^{*}$ & 1.00 & & & & \\
\hline Capital intensity 3 & $0.12^{*}$ & -0.02 & $0.12^{*}$ & $-0.06 *$ & -0.01 & -0.03 & $0.18^{*}$ & $-0.10^{*}$ & $-0.10^{*}$ & $-0.34^{*}$ & 1.00 & & & \\
\hline Pasture availability & 0.01 & $-0.05^{*}$ & $-0.06 *$ & $0.18^{*}$ & $-0.13^{*}$ & $0.11^{*}$ & $-0.16^{*}$ & $-0.08 *$ & $-0.11^{*}$ & 0.03 & -0.03 & 1.00 & & \\
\hline Fertilisers & $-0.39 *$ & 0.03 & $-0.07^{*}$ & -0.01 & $-0.12^{*}$ & 0.01 & $-0.21^{*}$ & $0.06 *$ & $0.23 *$ & 0.02 & -0.03 & -0.02 & 1.00 & \\
\hline Pesticides & $-0.25^{*}$ & -0.02 & $-0.07^{*}$ & -0.02 & $-0.13^{*}$ & $0.05^{*}$ & $-0.20^{*}$ & 0.00 & $0.14 *$ & $0.06^{*}$ & -0.00 & -0.02 & $0.36^{*}$ & 1.00 \\
\hline
\end{tabular}

$*=$ statistically significant at $5 \%$ 